\title{
Multimodality, Intertextuality and Carnivalism in the Fox and Gangnam Style as Gateways to Media Literacy
}

\author{
Eivind H. Karlsson \\ Oslo and Akershus University College of Applied Sciences, Faculty of Education and International Studies, Institute of Early Childhood \\ Education, Oslo, Norway
}

Email address:

Eivind.karlsson@hioa.no

\section{To cite this article:}

Eivind H. Karlsson. Multimodality, Intertextuality and Carnivalism in the Fox and Gangnam Style. Viral Music Videos as Gateways to Media Literacy. Humanities and Social Sciences. Vol. 4, No. 2, 2016, pp. 53-59. doi: 10.11648/j.hss.20160402.16

Received: February 20, 2016; Accepted: March 31, 2016; Published: May 5, 2016

\begin{abstract}
The essay aims to explain the viral dissemination of the Youtube videos "Gangnam Style" (2012) and "The Fox" (2013). The videos are treated as examples of the genre novelty songs. The method of the study is a close reading, focusing mainly on multimodality, intertextuality and carnivalism. The result of the analysis is identification of a number of coinciding elements in the two videos. The analysis also identifies a number of elements that demonstrate how the textual elements of the videos relate them to the properties of the new media, Web.2. In concluding, the essay argues that these videos are relevant as a common ground for school activities that aim to support the formation of the self of children in today's media reality.
\end{abstract}

Keywords: Media Literacy, Multimodality, Intertextuality, novelty song, Viral, Carnivalism, Cosmopolite

\section{Introduction}

The sudden popularity of Youtube videos like "Gangnam Style" (2012) and "The Fox" (2013) can be attributed to features of the so called Web.2. This term signifies the new generation's approach to the Internet. This includes the concepts of participatory cultures [1], spreadable media [2] and cosmopolitism [3]. According to Jung and Hongmei (2014), both the technological sides of internet (digital sharing tools, limitless connectivity), the media culture (responsiveness, cooperation) and the strategies of the artists (appearances in traditional media, renouncing copyrights) account for their potential for "going viral" [4].

However, there is a lack of analyses focusing on the unique features of the videos themselves, scrutinizing them from a textual point of view. The aim of this paper is to identify the elements in the negotiation of meaning carried by the modalities in the two Youtube video hits. Some common features in the motives suggest possible keys to addressing a young international audience.

Three concepts are of particular interest for the scope of this paper: Modalities, intertextuality and carnivalism. Modalities in music videos cooperate to provide possible meanings. Theory on modal texts [5] can clarify the contribution of each sign system used in a video. The concept of intertextuality [6] is an important factor in understanding the textual universe of web.2. The widespread term "parody", for example, is commonly used to describe mock elements in texts, but may include subtleties that add significantly to the allure of the videos and the play of texts in which they participate. Carnivalism is Mikhail Bakhtin's term for the essence of the carnival culture of the medieval times and the Renaissance [7]. He described a system of gestures, values and playfulness that dominated the European village marketplace, especially in the times of the Carnival. These ideas have proved to be of universal interest, occurring across time and cultures, for example on Youtube.

The paper starts out by presenting the videos and then moves on to argue that both videos belong to the genre novelty songs. The next part deals with the modalities of music videos, followed by a study of the cooperation between the modalities in the two videos at hand. The section about intertextuality focuses on direct and indirect references to traditional texts and genres, but also references to contemporary music videos.

In concluding, the paper suggests that making the videos part of the curriculum in schools could give teachers an opportunity to join the children in exploring Web.2. This approach could assist educators in promoting media literacy 
in a contemporary context and supporting the students' formation of the self, which develops inside and outside of classrooms.

\section{Presentation of the Two Videos}

When the Korean music artist Park Jae-sang («Psy») released his video «Gangnam Style» in 2012, it instantly peaked in the surveys. Its popularity is still unrivalled and it is registered with a total of more than 2,5 billion views (2016). Four types of content dominate the video: 1) The development of dance moves, 2) the places of the rich (as the paddocks) and the not so rich (as the mall), 3) Allusions (as the catwalk sequence which refers to fashion shows and 4) Guile: Close-up images are zoomed out, revealing the initial situation in reverse, as the close-up where he appears to be on the beach, but zoomed out turns out to be in the sand-box of the playground.

The film language of the video is rather conservative. The composition of the scenes is based on symmetry and on twodimensional arrays of dancers. Psy appears in almost monotonous frontality, but counteracted by his dance steps, suggestive poses and an almost acrobatic behaviour. A few scenes emphasise movement in a direction, for example the boat moving to the left, Psy pursuing a couple who walk backwards or Psy misbehaving in the river park. The editing involves various playback speeds, accelerating cross-cuts and jump cuts, disrupting the flow of time, also used in "Gentleman" (2013). The words describe the girlfriend of the Psy character, implying a glorification of a bohemian view of life. Wind machines, laser lights and a small fire bomb comprise the effects on the set, and there are no special effects.

The second music video, "The Fox" (2013), was first presented in a tv show in a Norwegian channel (I kveld med Ylvis on TV Norge). This show caters for teenagers and young adults, with a mix of skits, jokes and talk-show sessions. Music videos with a humoristic twist are part of the concept in these programmes. It was produced and directed by the company Stargate, who have also cooperated with performers like Beyoncé and Rihanna. The expenses of the video took one third of the show's budget for the whole season.

"The Fox" (2013) was also an immediate hit and it was awarded the trending Youtube video of the year in 2013 [8]. A more extensive presentation of the visual elements in "The Fox" (2013) will follow in section 4. Both videos have experienced dissemination following a pattern termed "going viral," meaning that social media have been vital for achieving the high ratings. [9]

Both videos are so-called novelty songs: humoristic and often parodic songs, introducing some inventive feature, like a dance move, a strange voice or a new sort of humour. The cowboy dance of Psy is original, as is the references to children's literature in Ylvis' video. Gurney [10] makes a connection between the comedy and the self-satire of viral music videos. The artists' mocking of the self makes it impossible for private contributors to mock the music video.
Instead, the social message which is often there becomes the focus of attention. When amateurs make parodies, it consequently involves adding content and messages, not impersonating or mocking the original.

\section{Multimodal Texts}

Music videos are multimodal texts that contain different meanings carried by different sign systems. In the negotiation between these meanings, the sign systems contribute with different parts. The Ylvis video can demonstrate the complexity. Here different modalities (semiotic resources) work together to create the overall impression, conveying whatever meaning is there. What such a modality actually is, is a point of dispute. Kress 2010 makes a long discussion short by proclaiming that a modality is a sign system that functions in a given social setting, and is recognised as a modality by the participants in this setting (2010: 79). There are four media present in the video: Sound, picture, writing and dance. Each medium carries different modalities.

The sound conveys the musical signs: The melody, the use of the voice, the arrangement and everything that is perceived as music. We could call it the musical denotation, meaning the musical elements that are immediately recognisable without much interpretation. In this case we hear a melody in $\mathrm{C \#}$ minor with a dominating bass and a regular pulse, generated electronically and mastered digitally. In addition the music creates certain connotations (associations that most listeners would be expected to have). "The Fox" is international dance music in a style one finds in the pop and dance charts. The intro resembles the sound of computer games like Super Mario (Nintendo). Among the sound signs are the lyrics, containing words. Words are conventional signs that appear along with the sound of the instruments. The meaning of these words decides how we understand the video as a whole. They have a high functional weight [11]. Intonation (use of the voice) and prosody (emphasis, tonal fluctuation and sound quantity) belong in part to the musical sphere and in part to oral language. In addition to all this, the listener exerts influence on how the song is perceived, by controlling the volume of the playback, setting the balance, playing through different sound mediating systems and so on.

The pictures move. The film modality is based on miscellaneous uses of colours, resolution, light, contrast, camera movements, cutting, composition and so on. Music videos follow particular conventions, and Ylvis' product is moderate, compared to many dance videos, which often consist of numerous ultra-short clips, often flashing in rhythm with the music. The moderate style of the movie language in "The Fox" (2013) makes this video available to a variety of listeners. In the moving pictures one notices two sorts of images that are not moving: The mask and the picture book. They both invite to a particular way of watching that requires an active and creative approach to questions like these: What does the fox on the back of the book look like? What is the motionless fox about to do? How 
does the mask change the identity of the person who carries the mask? Is it a camouflage or is it a stylized image that should be interpreted in a certain way? All of this the viewer must process while watching.

The letters are at the bottom of the picture, a line of written text. Writing is based on conventional signs with a given meaning, just like spoken words. Letters have a visual aspect, which consists of colour, placement in the picture and typographic effects, but in this video we see standardised texting/subtitles, of the sort that is usual in movies and on television, with a form that is intended to be easy to read and to have a minimal influence on the images. The letters here repeat the spoken words, but they add an element that challenges the reader, namely the numerous sound-imitating words (onomatopoeia). How is one supposed to read "jachachacha-chacha-chow"? Or rather: How can these sounds be represented in writing? The subtitles are not just a help to decipher the song, but also something quite the opposite: these recently created sound-words give the reader a challenge when it comes to finding a meaning with the whole video. The writing ensures extra emphasis on the sounds of the song, not the meaningful words. In addition to these letters, there is a big red and white logo in the shape of an "N" in one corner of the screen. This reminds us that the video is part of a concept on Tv Norge.

Dance is about bodies in movement. Here there is both free and choreographed dance. The movements of the fox convey the wild and untamed, while the movements of the dancers show the conventionalised and ritualised gestures of culture. Charles Sanders Peirce's categories of signs may be a help to sort the different types of movements [12]. First there are the iconic signs, that are signs that resemble the items they signify. When the dancers jump up and down with an arm in the air, they are a true copy of the crowds in a concert. The dancers also have another type of movement, movements that make the viewer think of a fox. They lift their hands to the side and bend their wrists. This is a movement that is quite dissimilar to a fox's natural movements. A real fox would not stand on two legs and display its claws and paws like that. But the dance leads the attention towards the hands and fingers of the dancers, that are bent, and in some respects may resemble claws. They indicate the beast-like in a way that may have some resemblance to the animal, but are mainly examples of conventions of what is perceived as animal-like. These are indexal signs, signs that are not iconic, but that indicate a certain origin or source. In addition the dancers exert movements that apparently have no direct connection to the context. Some arm movements may be signs that indicate that the video enters a new phase or sequence. When a new fox sound is presented, the dancers go into a new set of dance steps. These steps have no semantic connection to the words, other than the fact that they coincide rhythmically with the sounds of the music. These are arbitrary signs, true symbols, that function by convention, not by visual resemblance to any shape in nature or in culture. The hands put behind the backs of the dancers imitate soldiers at ease during an exercise. These movements are meta-signals: Here the dancers take a small break, while at the same time showing that they are disciplined. Their military poise also emphasises the fact that they wear a type of uniform.

These are the main sign systems at large in the video. They comprise modalities that come together to create a totality that we may call the meaning of the media text. We will later see how they influence each other in the course of the text. Several of the modalities are particularly important conveyors of meaning - they have high modal affordance [13]. This term indicates the meaning potential of the modality. Which modality has the highest affordance depends on how one interprets the video as a whole.

\section{The Modalities Cooperate}

The elements of the video work together. Both writing, pictures and sounds are present, conveying letters, logos, words, fixed and moving pictures, dance and different musical elements. These should all be read together as signs that form a text in the broad sense of the word.

Ylvis use the music style of dance music, and the video is designed to facilitate dance, as demonstrated by the dancers in the forest. Several of Ylvis' videos promote so-called flash mob dance, where a town square or a dance floor is occupied by a dance group who want to surprise their fellow townspeople and maybe invite bystanders to join. This has become part of the live broadcasts of the annual European Song Contest and has its roots in "The Bird Dance" (1981), "Macarena" (1995) and "Aserejé" (2002).

The movements in the text are a kinetic modality, and a carrier of meaning. Huizinga claims that rhythm, repetition, contrast, tension building and fall are qualities that belong to all sign systems based on the movements of the body, for example dance and poetry [14]. In "The Fox" (2013) poetry and movement is central, and the movements mean something. Huizinga associates them with play. When we move, we are involved in play. This play consists of kinetic elements. Mandoki [15] suggests these specifications of the kinetic basic elements: proxemics, kinetics, emphatics og fluxion. This includes for example static/dynamic, restricting/expanding, spin, fall, flux and emphasis. A child bobbing on the knee will experience many such movements in the play with the adult, and when movements, words and play join forces, it all converges into one impression of the text, in the broad sense of the word.

The term iconotext [16] sheds light on how modalities work together. Each sign system has a different task. In "The Fox" (2013) the verbal signs (the writing and the spoken words) have the style of a small children's picture book text. In addition there are some phrases of wonder and enchantment pertaining to the fox ("Your fur is red, so beautiful, like an angel in disguise"). The visual part of the product, however, tells us that there is a party, that someone takes an outsider's position, and that memories, impressions and nature experiences can go together in a strange night landscape, like a dream. Here the pictures interpret the text. 
The dancers demonstrate the use of the text: It is intended for the dancefloor.

The distribution of functional weight between the modalities makes it possible to enter into the different layers of fiction in the texts. In "The Fox" (2013) we see five different fox figures: The fox on the child's picture book, the fox characters of the dancers, the fox fursuiter-costumes, a life-like fox and a computer generated fox, which is the only special effect of the video. It is also interesting that we seem to view the forest through the eyes of the fox for a split second. At that moment we are the fox. Each fox image refers to the fox as culture and as nature, and they appear in different fictional layers in the multimodal text. Here are some examples of different layers in the video:

1. We see the video on the screen and enter the role as viewer, with a fictional contract with the narrative intention of the video.

2. The pictures tell about a party.

3. In this party a young man fantasises about a fox.

4. The young man at the party is instantly dressed in a fursuiter-costume as a fox. This could be a metacomment emphasising the fox theme of the song.

5. He appears in the forest with this costume on. This may be the fantasy of the young man, but on a more intense level.

6. The fox dance in the forest invokes a real life fox

7. This fox turns into a being which is a digitally constructed fox

8. This fox again enters the role of a scat artist.

Finally we're back on level 1, where we are helped out of the role of the viewer by the Ylvis brothers, who take off their costumes and walk away.

It becomes clear that there are numerous fictions within fictions. This way of presenting motives creates a refined iconotext. "The Fox" (2013) is both innovative and traditional. It makes use of different hypotexts in a text addressing readers with certain well defined competencies.

\section{Intertextuality}

Ylvis' song is about a certain type of children's literature: texts about animals for little children. The classical toddler's picture book often contains farm animals. The nursery rhyme often talks about mice and lambs. In the toddler literature animals and animal sounds are commonplace, firstly because children like animals, but also for another reason: When the little child points to an animal in the picture book, the adult reads the sound or mimics the sound. It is good entertainment to see an adult in the role of an animal, whether they low like cows, neigh like horses or bark like dogs. These texts have ample room for improvisation. The child who looks at the pictures and letters, points, and sees the response from the adult, will also learn something about how books work, both the reading direction, the principle of signs and the reading rhythm. A picture book used together with a child is most definitely a meta-text, in this case a text about how texts work.
Likewise, a popular video may function as an introduction to how different texts work for children of today. One step is recognising that texts refer to a universe of texts and should be interpreted in light of other texts. Genette terms old texts "hypotexts", while the newer texts referring to them are called "hypertexts". Ylvis' video is not only an echo of children's literature, it also echoes another type of texts, which function as hypotexts. Famous artists like Moby and Coldplay have made music videos with people in animal guise. A number of others can be found on Youtube, where Ylvis join the numbers of so-called «fursuiters», «furries», or «furry fans.» This is a phenomenon where people engage in play around beast-like identities. The obsession with animals brings to mind the tribal totem or the arch types of Carl Gustaf Jung. Mythological animals and mythological characters in animal disguise are universal motives in all cultures, and when children pretend to be animals in their play, they show the same propensity. Maurice Sendak's Where the wild things are (1963) is an example from children's literature where the author shows us the wildness of the main character by dressing him in an animal costume. This savage is redeemed through a process where the child has a fantasy about wild animal beings. The fursuits of Ylvis may serve to illustrate a certain wildness or unpredictability. It also serves as an example of intertextuality. A similar sort of party appears in Moby's «Beautiful» (2005), and the elephant appears in Coldplay's «Paradise» (2011). Both motives are part of «The Fox» (2013). But while the other artists treat serious issues like self awareness and estrangement, Ylvis focus on the trivia of life with their insisting rant about the sound of the fox.

This is a special type of intertextuality. In Gérard Genette's terminology many of the Ylvis videos would belong to what he calls the mock hero epos. In these texts one retains the style of the original, for example the hexameter of Homer. But motive and topic belong to a quite different and mundane sphere. O, Brother, Where art Thou [17] is a movie that illustrates this. This is a media text that transforms the original by keeping the multifaceted motive and mimicking much of the plot and the emotions, but replacing the hero and his antagonists with comical characters with petty personalities. The same comical effect can be found in parodies from children's traditional culture:

\footnotetext{
Children's version Original (John Henry Hopkins, Jr., 1857)

We three kings of Orient are, We three kings of Orient are

Tried to smoke a rubber cigar, Bearing gifts we traverse afar

It was loaded, Field and fountain,

It exploded, Moor and mountain

That's how we traveled so far! Following yonder star
}

When children sing this type of carol parody, it is testimony that they recognise that the carol genre requires rhymes and poetic phrases. The rhyming words in this mock version even contain the same sounds as in the hypotext. In this way there emerges a discrepancy between the traditional style and the surprising new Christmas motive, and the comical effect is ensured. 
In the case of "The Fox" we can also talk about transmotivation (Genette 1997: 330). The characters in other fursuiter-videos can expose their animal impulses through their suits. Sometimes they also use the fursuit in order to illustrate or process problems in life. Ylvis turn this motivation upside-down in their video. Yes, they are plagued, but not by the big issues of life, but by the fact that they don't know enough about the sound of an animal. The impression is, however, of the grand style, with passion in every gesture. As the viewer watches this, he is aware that the answer to their questions isn't further away than an internet search. This results in the parody. The style/motive is well known, but the topic or emphasis creates a break. In the case of "The Fox" (2013) it is not a canonical text that is mocked, this is popular music using popular music as material for a parody. In the process the hypertext ridicules itself and exalts the hypotexts.

\section{Themes in Common}

The two videos by Psy and Ylvis have several features in common, attributable to the arch-textuality that ties all texts together [18]. But these two texts are close, both regarding time of publishing, choice of media channel, audience and cultural context. They both are modern novelty songs with parodic elements, they both are videos made after the artists were firmly established, they both have striking similarities with former videos from the same artists, and they both experienced rapid success. Identifying some more particular similarities in the videos may be a step towards identifying the secret of their success.

First there is the motive. Both videos give a prominent place to the horse. The horse is an old symbol in both Eastern and Western culture, but in these two videos the horse is first and foremost connected to the lifestyle of the rich, and we find the horse in the carnival of the well-off (Ylvis) and in the posh stables of Psy. Also other animals are represented in both videos. We have already mentioned those of Ylvis. In "Gangnam Style" there are horses, but also swans (fairground boats with swan heads) and seagulls.

Children are also prominent figures. Ylvis show us the child on the lap, but also the adult behaving like a child. The same could be said of Psy. Quite early in his video he sits in the playground with children. Psy himself is playful right from the start, pretending to be on a beach, and having us fooled. His dance moves and extrovert body language could also be interpreted as references to the puerile sides of life. However, the child we meet early on in the video is a little dancer who turns out to be quite accomplished, with adult-like (Michael Jackson) body language and an adult-like hairstyle. There is a merging of the world of the child and the world of the adult and a confusion of the roles. This ambiguity is open to different interpretations. The child viewer may identify with the children, while the adult viewer may read this in a symbolic sense. Thus the videos address several audiences at once, like a so-called ambivalent text [19].

We also see the diegetic translocation in both cases. This is
Genette's term for stories taken out of their context and placed in a different time or place, like Shakespeare's Romeo and Juliet finding its way to the streets of New York in West Side Story (1957). The red carpet walk of Hollywood is translocated to the concrete jungle, with garbage in the air instead of confetti. In "The Fox" the furry symbols of Moby and Coldplay are transferred into a very real forest in Norway, where the animal actually comes to life. The daydream loses its ephemeral lure and crashlands in a mundane and tangible reality.

There is an element of the carnivalesque in both videos. This is a term coined by Mikhail Bakhtin describing the culture of the medieval and renaissance, where society in many parts of Europe had a tradition of feast at certain times of the year [20]. This "Carnival" time invited all members of the local community to treat their village as a stage where life was enacted in certain ways: The rich were starved, the mighty beaten, the poor were served the best food and the choir boy could become bishop for a week. This subversion of life meant that what was exalted was allowed to be degraded, what was individual became collective, and what was normal was reversed. The lower strata of the body were subject to exaltation. Excrements and procreation alike were part of the acts of the village scene. This coincides with the notion of a collective existence, where what we eat in turn becomes a substrate for new crops in the fields, where dying means endowing the world with fertile dust, and where food grown in this soil in turn gives life to people and strength to create new offspring. The gestures and shapes that protrude from the body and the body cavities express these processes. Understanding the enactments of the carnival involves identification of these elements and seeing them as part of a big picture.

Both videos have carnivalesque features. Firstly, they refer to sex. There is suggestive pole dancing in the subway. Psy's lyrics, with "bulging muscles" and "bulging ideas", are a carnivalesque tendency. The obsession with hind parts in one scene is part of the same picture. This scene is a graphic match to a popular video by Eric Prydz, "Call on me" (2004), with explicit erotic content. In the elevator scene there is body language of unequivocal sexual character. Here the protagonist is placed on the ground, as a physical expression of the subversive element: The mind and the cognitive is superseded by the lower bodily functions, and it all culminates in the toilet scene. Eating is also represented, as in the red carpet scene, where Psy actually seems to be eating garbage. With the close-up/zoom-out effect the lower strata of the body - the situation on the toilet - is contrasted with the upper - the head that relates to its surroundings with words.

Ylvis also show the carnivalesque, for example in the forest dance. Here there is a merger between the feminine and masculine in the costumes of the dancers. The dancers act as a collective, and the movements are those of protruding gestures. The words are no longer analytical or meaningful, but imitations or experimentation evolving around the animal-like. The animal-like behaviour of the 
dancers emphasises the wild and sexual side of the women, whereas the misplacement of the office suit into the forest could represent a degradation of law, order and civil life. We see how the meal of the feast in the opening scenes introduces the carnivalesque elements later in the video. The eating of the crisps resembles the meal of the holy communion. The common fox is called a guardian angel, and this implies a degradation of what is holy. The holy communion is a common motive in the carnival celebrations of old. The symbolism is similar: The saviour is treated like a criminal, his holy body becoming food as a symbol of the fellowship of believers. Ylvis elevate the fox to the position of the angel, both in the text and physically, demonstrating a tendency that matches the theories of Bakhtin quite accurately. It is also interesting to notice that all generations are present in both videos. The videos comment on life in its different phases, implying a universal perspective.

\section{Media Literacy and Formation of the Self}

These two texts are part of a textual universe and of a cosmopolite world that the school may want to address. "Increasingly, the local and the global intermingle and overlap in everyday practices (...) We are increasingly acting and thinking as "citizens of the world"", says Lindell [21]. The cultural situation of youth today is that of instant connectivity to peers around the world, using English as a lingua franca and exploring many of the same digital applications and games. This doesn't mean that people's local experiences and differences are unimportant, but it means that they increasingly lead their lives keeping in mind that what they do has bearings on the world, and vice versa.

Notions of local and global play a part in the possible meaning of the videos: The local Norwegian Fox can be read as a symbol of the unobtainable. As the Fox steps into the digital realm it becomes relevant to online youth everywhere. The Gangnam motive is similar: Local figures of pretend wealth demonstrate a yearning for what is not obtainable by most: the lifestyle of the rich. These messages seem to speak to vast crowds, and this may be attributable to the combination of local and global elements in the videos. The audiences may furthermore create their own versions, the parodies, and connect to the local or the global elements of the motive, and share globally on Youtube.

By making viral hits part of our classes and putting effort into analysing them, we promote media literacy. Common to most definitions of media literacy is the idea that media competencies enhance the individual's ability to attain information, to participate in society and pursue their rights [22]. Access to "The Fox" and "Gangnam Style" is something most people have at home. But do children have access to it in kindergarten or in school? Sometimes texts appear and create an oppportunity for rethinking some educational principles. An analysis of such videos requires that one is able to sort different modalities from each other, identify the ways they coexist and identify how they refer to other texts. The pedagogue can join the pupils and look past the intuitive impression of the text, try to find out how the text works and stimulate reflection. If the pupils want to evaluate the text, it requires criteria, criteria that need to be discussed and written down. Now the elements of the analysis must be shaped as arguments. They are repeated and expanded and may give impulses to creating oral texts, written texts or media texts. We know that children at home use many tools to make their own media texts. Many kindergartens have succeeded with creating parody videos with the children based on Gangnam Style and The Fox.

The videos may inspire a plethora of relevant activities: To explore our concepts of poverty or greed, to go on hikes in the forest, to talk about the world and its texts. The making of new videos may lead to discussions about humour and parody, music, rebellion and also listening habits. Gender roles turn up in interesting ways in "The Fox" and "Gangnam Style." Anthropomorphism in the motive may create interest for deep talks about Man, animals, nature and religion. Intertextuality becomes interesting through references to other music videos, and here young people may prove themselves to be resourceful guides to the learning landscape we create in the classroom.

By working with awareness and responsibility the school promotes formation of the self. Formation of the self has traditionally been associated with regard of cultural heritage and canonical works [23]. Others propagate a less hegemonic view of self formation where the individual is not a mere receiver of transferred wisdom and knowledge, but actively forms himself in dialogue with his cultural and social environment [24].

Private persons and owners of Youtube channels make their own versions of the videos, and the original text gets a new form and new functions. Just 14 days after the video was launched, the Youtube channel Jinnyboytv published his video "Ylvis - "The Fox" Parody (The Drama)," where the plot is set in some kind of soap opera reality in Malaysia. "Gangnam Style" is subject to countless parodies, and the number of clips continues to grow. Minecraft in particular is a digital platform that has become part of children's culture, and where they are free to make their own games and play a combination of construction play and role play. By means of the building blocks from Minecraft and the recording options of the computer, children have made numerous versions of "Gangnam Style" and "The Fox." Such examples demonstrate how actively children can relate to videos and how easily they create their own.

Viral videos become common experiences for whole generations of young media consumers and will serve as a reference for them throughout their lifetime, with bearings of their preferences, media awareness and cosmopolite world view. The videos will consequently be part of a process of formation of the self across the Globe. The active approach from the consumers that the videos facilitate could mean a step away from a hegemonic view of self formation and towards an egalitarian and dynamic thinking. John Dewey 
states that formation of the self is always a political project. He is also concerned that formation of the self should not be isolated from first-hand experience. According to Dewey formation starts when body and mind go through experiences that require problem solving activities in cooperation with others [25]. Such activities are what this article is about. That young people "actively form themselves in dialogue with their cultural and social environment" [26] is something that school and kindergarten can support, but not decide. We can invite the pupils to work with the viral videos. Leaving to the pupils to administer some of the learnings processes may prove to be the wisest move the school can make.

\section{Conclusion}

The two novelty song videos "Gangnam Style" (2012) and "The Fox" (2013) are examples of digital texts of extraordinary popularity online. Their appeal can be explained by their advanced uses of the different modalities and by their embedding in an intertextual play. The motive in both videos refers to a sense of yearning, a heritage from the romantic period, and to the carnival culture of the Medieval and Renaissance described by Bakhtin. These elements, along with their use of English as a lingua franca, prove to be popular with their young and cosmopolite audience. Pedagogical institutions should include such texts in their pedagogical practice to promote media literacy and formation of the self.

\section{References}

[1] Burgess, J., \& Green, J. (2009). YouTube: Online video and participatory culture. Cambridge, UK: Polity. doi: 10.1080/15405700903502312 niversity of California Press.

[2] Jenkins, H., Ford, S., \& Green, J. (2013). Spreadable media: Creating value and meaning in a networked culture. New York, NY: New York University Press.

[3] Jenkins, H. (2004). Pop cosmopolitan. In M. M. SuarezOrozco \& D. B. Qin-Hilliard (Eds.), Globalization culture and education in the new millennium (pp. 114-140). Los Angeles, CA: University of California Press.

[4] Jung, Sookeung and Li Hongmei (2014). Global Production, Circulation, and Consumption of Gangnam Style. In International Journal of Communication 8 (2014), 2790-2810.

[5] Kress, Günther (2010). Multimodality. A social semiotic approach to contemporary communication. London and New York: Routledge.

[6] Genette, Gerard (1982, 1997). Palimpsests. Literature in the second degree. Lincoln/London: University of Nebraska Press.

[7] Bakhtin, Mikhail (1984/1965). Rabelais and His world. Indiana University Press. First published in Russian in 1965.

[8] http://gizmodo.com/here-are-the-most-popular-youtubevideos-of-2013-1480614567. Retrieved 23 March 2016.
[9] Jung, Sookeung and Li Hongmei (2014). Global Production, Circulation, and Consumption of Gangnam Style. In International Journal of Communication 8 (2014), 2790-2810.

[10] Gurney, David (2011). Velvet Light Trap: A Critical Journal of Film \& Television. 2011, Issue 68, p3-13.

[11] Kress, Günther (2003). Literacy in the New Media Age. London: Routledge.

[12] Peirce, Charles S. (1894). «What is a sign». See http://www.iupui.edu/ peirce/ep/ep2/ep2book/ch02/ep2ch2.ht m, retrieved 23 March 2016.

[13] Kress, Günther (2010). Multimodality. A social semiotic approach to contemporary communication. London and New York: Routledge.

[14] Huizinga, Johan (1938, 1955). Homo Ludens: A Study of the Play-Element in Culture. Boston: The Beacon Press, see page 142.

[15] Mandoki, Katya (2007). Everyday Aesthetics: Prosaics, the Play of Culture and Social Identities. Hampshire: Ashgate. See page 151 .

[16] Hallberg, Kristin (1982): Litteraturvetenskapen och bilderboksforskningen. I Tidskrift för litteraturvetenskap, 1982 nr. 3-4.

[17] Coen brothers (2000). O Brother, Where Art Thou.

[18] Genette, Gerard $(1982,1997)$. Palimpsests. Literature in the second degree. Lincoln/London: University of Nebraska Press, see page 1.

[19] Shavit, Zohar (1980). The Ambivalent Status of Texts: The Case of Children's Literature. Poetics Today. Vol. 1, No. 3, Special Issue: Narratology I: Poetics of Fiction (Spring, 1980), pp. 75-86. Duke University Press.

[20] Bakhtin, Mikhail (1984/1965). Rabelais and His world. Indiana University Press. First published in Russian in 1965.

[21] Lindell, Johan (2014). Cosmopolitanism in a medialized world. The Social Stratification of Global Orientations. Karlstad university studies. See page 14.

[22] Ngozi, Chilaka (2013). A Literature Review On Media Literacy. Retrieved 38 March 2016. https://stripesarticles.wordpress.com/page/2/

[23] Sorkin, David (1983). Wilhelm Von Humboldt: The Theory and Practice of Self-Formation (Bildung), 1791-1810. Journal of the History of Ideas Vol. 44, No. 1 (Jan. - Mar., 1983), pp. 55-73. University of Pennsylvania Press.

[24] Østerud, Svein (2007). Krever medieutviklingen en ny dannelsestenkning? In Vettenranta, Soilikki (red.): Mediedanning og mediepedagogikk. Fra digital begeistring til kritisk dømmekraft. Oslo: Gyldendal akademisk. See page 39.

[25] Dewey, John (1985). Demokrati och utbildning. Gøteborg: Daidalos.

[26] Østerud, Svein (2007). Krever medieutviklingen en ny dannelsestenkning? In Vettenranta, Soilikki (red.): Mediedanning og mediepedagogikk. Fra digital begeistring til kritisk dømmekraft. Oslo: Gyldendal akademisk. 